University of Nebraska - Lincoln

DigitalCommons@University of Nebraska - Lincoln

Mammalogy Papers: University of Nebraska

State Museum

Museum, University of Nebraska State

1980

\title{
Analysis of Sonagrams of American Bison (Bison Bison)
}

Harvey L. Gunderson

University of Nebraska-Lincoln

Brian R. Mahan

University of Nebraska State Museum

Follow this and additional works at: https://digitalcommons.unl.edu/museummammalogy

Part of the Zoology Commons

Gunderson, Harvey L. and Mahan, Brian R., "Analysis of Sonagrams of American Bison (Bison Bison)" (1980). Mammalogy Papers: University of Nebraska State Museum. 159.

https://digitalcommons.unl.edu/museummammalogy/159

This Article is brought to you for free and open access by the Museum, University of Nebraska State at DigitalCommons@University of Nebraska - Lincoln. It has been accepted for inclusion in Mammalogy Papers: University of Nebraska State Museum by an authorized administrator of DigitalCommons@University of Nebraska Lincoln. 


\section{ANALYSIS OF SONAGRAMS OF AMERICAN BISON (BISON BISON)}

The sound made by adult male American bison (Bison bison) during agonistic behavior has been described as a "roar" because of its similarity to the roar of an African lion (Shult, 1972). Bulls roar any time of the year, but more commonly and most intensively during the rut when there are many agonistic confrontations between competing males. McHugh (1958), Shult (1972), and Petersburg (1973) have described this roaring and under what circumstances it occurs.

While the bull is roaring, its tongue is protruded and the sound is produced by forceful expiration of air over the vocal cords. In contrast, the "mooing" and loud "bawling" or "bellowing" of domestic cows and bulls (Bos taurus) are produced by both expiration and inspiration of air over the vocal cords (Kelemen, 1963).

The basic sound made by bison is a grunt. This varies from the barely audible vocalization of young calves to the loud roaring of the bulls. Although more common among bison bulls, cows protecting their newborn calves also roar (Mahan, 1978), but not as loudly as bulls. Sounds usually made by bison cows consist of soft gutteral grunts. Calves produce higher pitched grunts, often in response to their dam's somewhat louder grunting. Calves also bleat loudly, usually during active chases and play fights with other calves. Grunting occurs at all times of the year, but more frequently when the calves are very young and again when the calves begin leaving the cow and forming subgroups within the herd. McHugh (1958) discussed the function and occurrence of the sounds made by bison cows and calves. In general, their vocalizations are comparable in sound and function to that of domestic cows and calves.

Except for Tembrock's (1963:759) report listing the principal frequencies of "bleating calls" of an American bison cow and a European bison (Bison bonasus) cow, each with a calf, there are no published descriptions of bison vocalizations based on the analysis of sound spectrographs (sonagrams). The objective of this paper is to describe quantitatively vocalizations of bison, in particular the roar of the adult males.

Materials and methods.-Tape recordings of vocalizations were made in a bison herd of approximately 300 animals at Fort Niobrara National Wildlife Refuge, Valentine, Nebraska on 30 July 1967, 29 October 1970, and 30 July-1 August 1973. Vocalizations were recorded on a Sony Tapecorder Model TC-800 at $19 \mathrm{~cm} / \mathrm{s}$ with an Electro-Voice Model 674 microphone. In those made in July 1967 and October 1970, the microphone was mounted in a parabolic reflector. No reflector was used for those recorded in 1973. Distances from the subjects ranged from 5 to 20 $\mathrm{m}$. Sonagrams were made on a Kay Electric Company 6061B Sona-graph using the narrow band filter, with the reproduce circuit set at $80-8000 \mathrm{~Hz}$.

Results and discussion.-The duration, fundamental and dominant frequencies, and approximate highest harmonic of two calf and two cow grunts, and 21 roars by bulls are given in Table 1. Sonagrams of the calves, cows, and six of the bulls are shown in Figure 1.

Vocalizations of cows and calves were considerably shorter in duration and of higher frequency overall than the roars of the bulls. The roars ranged in duration from 0.5 to $5.8 \mathrm{~s}$ (Table 1). It appeared that the duration of a roar was dependent on the intensity of the confrontation. Other researchers have reported that the roars of bulls lasted 1 to $10 \mathrm{~s}$, generally 5 or $6 \mathrm{~s}$ (McHugh, 1958; Shult, 1972; Petersburg, 1973). Although the beginning of a roar was easily determined, the ending was not because the roar often diminished in volume, as can be seen on some of the

TABLE 1.-Duration, fundamental and dominant frequencies, and highest harmonic of bison vocalizations.

\begin{tabular}{lclcccc}
\hline & $\mathrm{N}$ & & Duration(s) & $\begin{array}{c}\text { Fundamental } \\
\text { frequency }(\mathrm{Hz})\end{array}$ & $\begin{array}{c}\text { Dominant } \\
\text { frequency }(\mathrm{Hz})\end{array}$ & $\begin{array}{c}\text { Approximate highest } \\
\text { harmonic }(\mathrm{Hz})\end{array}$ \\
\hline Bulls & 21 & Mean & 2.05 & 230 & (same as & 3,590 \\
& & Range & $0.5-5.8$ & $155-330$ & fundamental) & $1,500-7,500$ \\
Cows & 2 & Mean & 0.55 & 270 & 2,040 & 5,250 \\
& & Range & $0.5-0.6$ & $230-345$ & $1,925-2,156$ & $3,500-7,000$ \\
Calves & 2 & Mean & 0.2 & 250 & 1,155 & 3,500 \\
& & Range & 0.2 & $230-270$ & 1,155 & both 3,500 \\
\hline
\end{tabular}



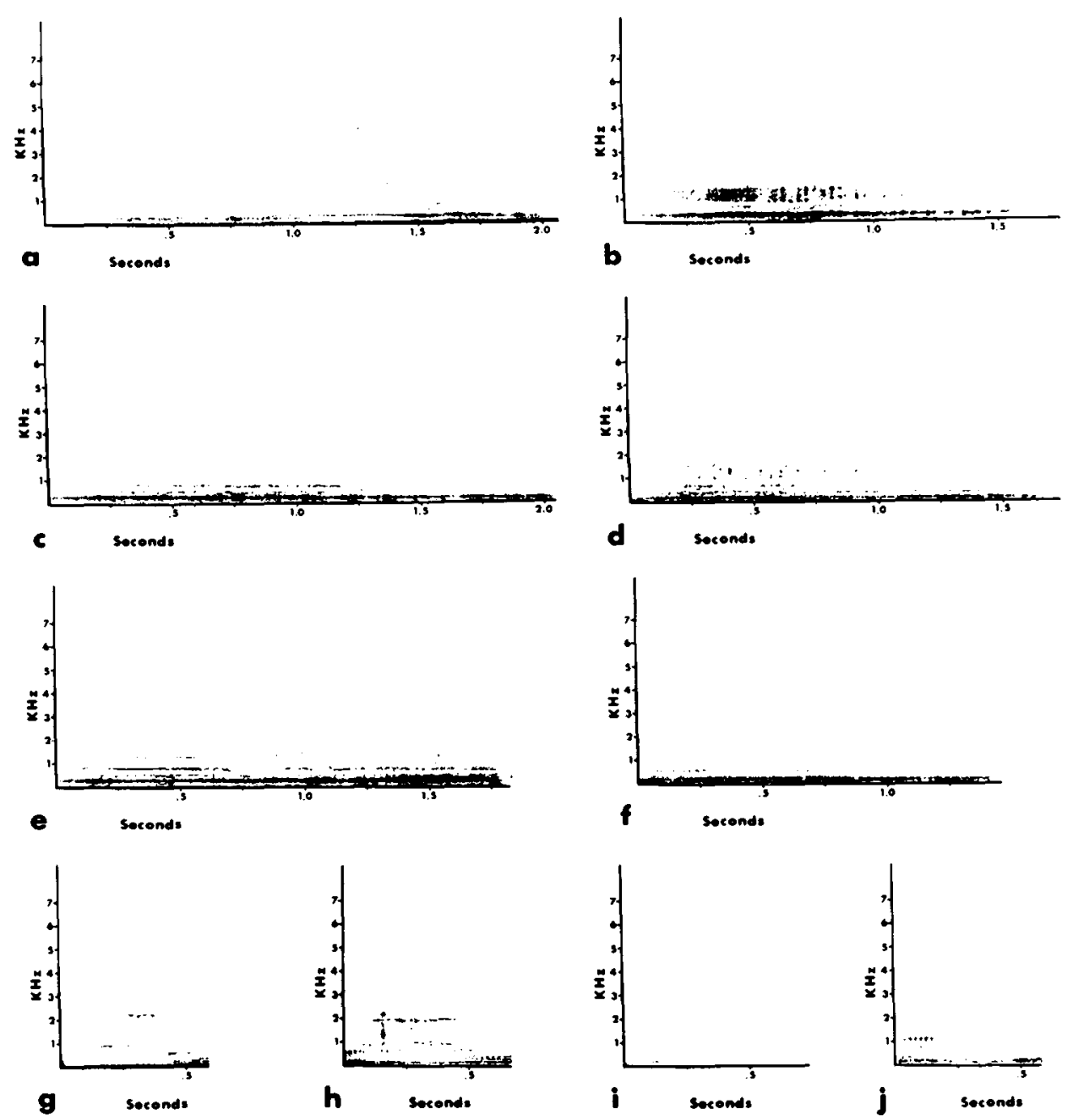

Fig. 1.-Sonagrams of bison vocalizations: six bulls (a-f), two cows ( $g, h$ ), and two calves (i, j). (Due to photographic reproduction, several additional harmonics in a are not visible.)

sonagrams (Fig. 1). Harmonics were detected on the cow, calf, and several of the bull sonagrams (Fig. 1). Generally, the harmonics of the roars were of short duration and low frequency; however, Fig. 1a illustrates a roar unusually rich in harmonics.

Numerous histological and genetic studies of domestic cattle $\times$ bison hybrids have been studied to determine the taxonomic status of the two genera (Basrur and Moon, 1967; Fedyk and Sysa, 1971; Dziurdzik, 1978). Differences in morphological characters have been used to separate the genus Bos from Bison. However, similarities of blood group characters have been used as evidence for combining the genera (Stormont et al., 1961). Further investigation and comparisons of vocalizations plus study of the comparative anatomy of the larynx might be profitable in illuminating the relationships and evolution of these two taxa.

We appreciate the cooperation of the staff at Fort Niobrara National Wildlife Refuge. We also thank Dr. R. B. Goldstein of Creighton University for preparing the sonagrams, his advice during their analysis, and his critical review of the manuscript, and Ms. M. Mergler Niemeier and Dr. P. A. Johnsgard for their advice and critical review of the manuscript. The microphone and 
parabolic reflector were purchased with funds provided by a grant from the University of Nebraska Research Council.

\section{Literature Cited}

Basrur, P. K., AND Y. S. MoON. 1967. Chromosomes of cattle, bison, and their hybrid, the cattalo. Amer. J. Vet. Res., 28:1319-1325.

DZIURDZIK, B. 1978. Histological structure of the hair in hybrids of European bison and domestic cattle. Acta Theriol., 23:277-284.

FEDYK, S., AND P. SYSA. 1971. Chromosomes of European bison, domestic cattle and their hybrids. Acta Theriol., 16:465-470.

Kelemen, G. 1963. Comparative anatomy and performance of the vocal organ in vertebrates. Pp. 489-521, in Acoustic behaviour of animals (R.-G. Busnell, ed.). Elsevier Publ. Co., Amsterdam, 933 pp.

MCHuGH, T. C. 1958. Social behavior of American buffalo (Bison bison bison). Zoologica, 43:1-40.

MAHAN, B. R. 1978. Aspects of American bison (Bison bison) social behavior at Fort
Niobrara National Wildlife Refuge, Valentine, Nebraska, with special reference to calves. Unpubl. M.S. thesis, Univ. of Nebraska, Lincoln, $171 \mathrm{pp}$.

Petersburg, S. J. 1973. Bull bison behavior at Wind Cave National Park. Unpubl. M.S. thesis, Iowa State Univ., Ames, 302 pp.

SHULT, M. J. 1972. American bison behavior patterns at Wind Cave National Park. Unpubl. Ph.D. dissert., Iowa State Univ., Ames, $178 \mathrm{pp}$.

Stormont, C., W. J. Miller, and Y. SuzuKI. 1961. Blood groups and the taxonomic status of American buffalo and domestic cattle. Evolution, 15:196-208.

TEMBRoCK, G. 1963. Acoustic behaviour of mammals. Pp. 751-786, in Acoustic behavior of animals (R.-G. Busnell, ed.). Elsevier Publ. Co., Amsterdam, 933 pp.

HARVEY L. GUNDERSON AND BRIAN R. MAHAN, University of Nebraska State Museum, W436 Nebraska Hall, University of Nebraska, Lincoln, NB 68588. Submitted 12 March 1979. Accepted 7 November 1979.

J. Mamm., 61(2):379-381, 1980 